\title{
Plasma Allantoin Concentration and Urinary Purine Derivatives to Creatinine Ratio are not Sensitive Estimator of Microbial Protein Supply in Calves
}

\author{
Tsunenori IrIKI, Masayuki Funaba, Motoko Hatano \\ and Matanobu ABE \\ School of Veterinary Medicine, Azabu University, \\ Sagamihara-shi 229
}

(Received March 22, 1994)

Key words : plasma allantoin, urinary purine derivatives, rumen microbial protein, calf

Urinary excretion of purine derivatives (PD), xanthine, hypoxanthine, uric acid and allantoin, by ruminants has been proposed as a good estimator of the intestinal flow of microbial protein synthesized in the rumen ${ }^{8,15)}$. A series of our studies have shown that urinary PD could apply to calves, except for calves just after early-weaning ${ }^{1,3)}$.

Recently, CHEN et al. ${ }^{7)}$ suggested that both plasma concentration of allantoin and the urinary $\mathrm{PD}$ : creatinine ratio might be also suitable for use as an alternative to daily PD excretion to give an indication of microbial protein production in steers, although the sensitivity remained to be unclear. Because of a singletime measurement without collecting urine for all day, these parameters might be able to be useful under practical farm condition. However, Puchala and KulaseK ${ }^{13)}$ reported that urinary allantoin : creatinine ratio had rather large variation within a day in sheep, suggesting the unreliability for estimating microbial protein production. This study was conducted to evaluate the sensitivity of plasma allantoin concentration and urinary $\mathrm{PD}$ : creatinine ratio in calves.

\section{Materials and Methods}

Animals and feeds: Plasma allantoin concentration and urinary excretion of $\mathrm{PD}$ and creatinine were determined in two experiments using each 9 male Holstein calves $(\mathrm{ca} .140 \mathrm{~kg}$ ) in a $3 \times 3$ Latin square design. To maintain the functioning of esophageal groove closure for casein administration into the abomasum, the suspension was given by a nipple method under a constant auditory environment in addition to routine noises in succession to the suckling period of milk replacer.

Treatments compared in Exp. 1 were as follows ; (A) basal diet consisted of $10.0 \%$ rice straw, $88.2 \%$ flaked corn, $0.45 \% \mathrm{NaCl}, 0.90 \%$ $\mathrm{CaCO}_{3}$, and $0.45 \%$ trace mineral and vitamin mixture (CP : $7.9 \%$; TDN : $74 \%$ ), (B) $1.44 \%$ urea

血繁アラントイン濃度および尿中プリン誘導体ークレアチニン比は仔牛の微生物態蛋白澌供給量の鋭敏な指標では ない: 入来常徳・舟場正幸・烟野元子・阿部又信（麻布大学獣医学部，相模原市，229） 
supplement in place of flaked corn of the basal diet, and $(\mathrm{C})$ iso-nitrogenous casein administration into the abomasum instead of urea, in addition to (A). Treatments compared in Exp. 2 were as follows; (D) basal diet consisted of $10.0 \%$ rice straw, $79.2 \%$ flaked corn, $7.65 \%$ soybean meal, $0.90 \% \mathrm{NaCl}, 1.80 \% \mathrm{CaCO}_{3}$, and $0.45 \%$ trace mineral and vitamin mixture $(\mathrm{CP}$ : 10.4\% ; TDN : 73\%), (E) $1.17 \%$ urea supplement in place of flaked corn of the basal diet, and (F) iso-nitrogenous casein administration into the abomasum instead of urea, in addition to (D). In both experiments, the calves were given diets daily at $2.7 \%$ of initial $\mathrm{BW}$ in each period, resulting in the $\mathrm{CP}$ intake $2.1 \mathrm{~g} / \mathrm{kg} \mathrm{BW}$ for (A), $3.2 \mathrm{~g} / \mathrm{kg} \mathrm{BW}$ for (B) and (C), $2.8 \mathrm{~g} / \mathrm{kg} \mathrm{BW}$ for (D), and $3.7 \mathrm{~g} / \mathrm{kg} \mathrm{BW}$ for $(\mathrm{E})$ and $(\mathrm{F})$. Calves were offered the diets and casein suspension at 08 : 30 and $16: 30$.

Trials and analyses: Urine was collected for last $4 \mathrm{~d}$ of $2 \mathrm{wk}$ period into $300 \mathrm{~m} l$ of $20 \%(\mathrm{v} / \mathrm{v})$ $\mathrm{H}_{2} \mathrm{SO}_{4}$, and blood was taken by jugular vein puncture on the last day of each period at 08 : $00,10: 30,12: 30,14: 30$ and $16: 30$. Urinary allantoin was determined by the method of YOUNG and CONWAY ${ }^{16}$. Plasma allantoin was also analyzed after deproteinization and defatted by the same procedure. Uric acid was determined using a commercial kit (Uric Acid C-Test, Wako, Tokyo). Because hypoxanthine and xanthine were not usually detected in urine of cattle ${ }^{4}$, the sum of uric acid and allantoin was regarded as PD.

Data were analyzed by analysis of variance for Latin square design using the GLM procedure of SAS ${ }^{14)}$. When the effect of treatment was significant $(P<0.05)$, means among the treatment groups were compared by Duncan's multiple range test (alpha $=0.05$ ). Further, to examine the interaction of the changes in plasma allantoin concentrations within a day and treatments, factors considered were treatment, period, animal, sampling time, and interaction of treatment and sampling time.

\section{Results and Discussion}

Table 1 shows $\mathrm{CP}$ intake related to $\mathrm{BW}, \mathrm{N}-$ intake, urinary excretion of $\mathrm{PD}$ and plasma allantoin concentration in calves different in daily $\mathrm{N}$-intake. The intakes of $\mathrm{CP}$ from the basal diet were 2.1 and $2.8 \mathrm{~g} / \mathrm{kg} \mathrm{BW}$, and the intakes of supplemental CP by urea or casein were 1.1 and $0.9 \mathrm{~g} / \mathrm{kg} \mathrm{BW}$ in Exp. 1 and 2, respectively, leading to the variable $\mathrm{CP}$ intake (2.1 to $3.7 \mathrm{~g} / \mathrm{kg} \mathrm{BW}$ ). According to $\mathrm{NRC}^{12}$, calves weighing $150 \mathrm{~kg}$ require $639 \mathrm{~g}$ dietary $\mathrm{CP}$ for $1.0 \mathrm{~kg}$ of daily gain $(4.3 \mathrm{~g} \mathrm{CP} / \mathrm{kg} \mathrm{BW})$. Our previous report ${ }^{2)}$ also showed that urea supplement to the basal diet consisted of corn and soybean meal increased $\mathrm{N}$-retention up to the intake of $3.3 \mathrm{~g} \mathrm{CP} / \mathrm{kg}$ BW in calves weighing 120-180 kg. At least calves fed only the basal diet (i.e.,(A) and (D) group in Exp. 1 and 2, respectively) are thought to be unable to meet $\mathrm{N}$-requirement. Therefore, the increase in microbial protein prodoction due to urea supplement (i.e., (B) and (E) group) would improve $\mathrm{N}$-balance.

In fact, urinary PD increased 1.38 and 1.41 times by urea supplement in calves, compared with those fed the basal diet and those administrated casein, respectively, in Exp. 1. When calves were given the basal diet at $2.8 \mathrm{~g}$ $\mathrm{CP} / \mathrm{kg} \mathrm{BW}$ in Exp. 2, it also caused the increase in urinary $\mathrm{PD}$, suggesting the reliability of urinary $P D$ as an estimator of microbial protein supply. Further, urinary PD tended to be higher in calves ingested $2.8 \mathrm{~g} \mathrm{CP} / \mathrm{kg}$ BW than in those ingested $2.1 \mathrm{~g} \mathrm{CP} / \mathrm{kg} \mathrm{BW}$, although the comparison could not be evaluated statistically. Matsuoka et al. ${ }^{10)}$ showed the positive relationship between DCP intake and urinary allantoin excretion in sheep fed the low to moderate CP diets. MATsumoto et al. ${ }^{9)}$ reported that urinary excretion of allantoin was increased not only by the elevation of dietary $\mathrm{CP}$ levels but also by the higher degradability in goats.

Urea supplement to the basal diet caused a 
Table 1. Daily $\mathrm{CP}$ intake related to $\mathrm{BW}, \mathrm{N}$-intake, urinary excretion of purine derivatives (PD) and the ratio to creatinine $(\mathrm{C})$, and plasma allantoin concentration in calves supplemented urea to the diet or administered casein into the abomasum

\begin{tabular}{|c|c|c|c|c|c|c|c|c|}
\hline & \multicolumn{4}{|c|}{ Exp. 1} & \multicolumn{4}{|c|}{ Exp. 2} \\
\hline & $\mathrm{A}$ & $\mathrm{B}$ & $\mathrm{C}$ & SEM & $\mathrm{D}$ & $\mathrm{E}$ & F & SEM \\
\hline $\begin{array}{l}\text { Daily CP intake } \\
(\mathrm{g} / \mathrm{kg} \mathrm{BW})\end{array}$ & 2. 1 & 3.2 & 3.2 & & 2.8 & 3.7 & 3.7 & \\
\hline $\mathrm{N}$-intake $(\mathrm{g} / \mathrm{d})$ & $52.3^{\mathrm{b}}$ & $81.2^{\mathrm{a}}$ & $78.7^{\mathrm{a}}$ & 0.9 & $61.5^{\mathrm{b}}$ & 83. $1^{\mathrm{a}}$ & $81.2^{\mathrm{a}}$ & 0.6 \\
\hline From basal diet & 52.3 & 52.4 & 49.9 & 0.2 & 61.5 & 61.9 & 60.6 & 0.1 \\
\hline From urea & & 28.8 & & 0.1 & & 21.2 & & 0.1 \\
\hline From casein & & & 28.9 & 0.1 & & & 20.6 & 0.1 \\
\hline \multicolumn{9}{|c|}{ Urinary PD (mmol/d) } \\
\hline Uric acid & $1.6^{\mathrm{a}}$ & $1.8^{\mathrm{a}}$ & $1.3^{b}$ & 0.1 & 1.7 & 2.0 & 1.8 & 0.1 \\
\hline Allantoin & $38.3^{b}$ & 53. $3^{\mathrm{a}}$ & $37.4^{\mathrm{t}}$ & 1.2 & 52.3 & 57.8 & 52.1 & 1.7 \\
\hline PD & $39.9^{b}$ & $55.1^{\mathrm{a}}$ & $39.1^{b}$ & 1.2 & $54.0^{\mathrm{b}}$ & $59.8^{a}$ & $53.9^{b}$ & 1.7 \\
\hline $\mathrm{PD} / \mathrm{C}(\%)$ & $1.14^{\mathrm{b}}$ & 1. $45^{\mathrm{a}}$ & $1.11^{\circ}$ & 0.04 & $2.04^{\mathrm{a}}$ & $2.07^{\mathrm{a}}$ & $1.87^{b}$ & 0.05 \\
\hline \multicolumn{9}{|l|}{$\begin{array}{l}\text { Plasma allantoin } \\
(\mu \mathrm{mol} / l)\end{array}$} \\
\hline $08: 30$ & $150^{\mathrm{b}, *}$ & $186^{\mathrm{a}}$ & $143^{b}$ & 9 & 167 & 158 & 157 & 8 \\
\hline $10: 30$ & 130 & 153 & 121 & 9 & 212 & 194 & 188 & 7 \\
\hline $12: 30$ & 147 & 158 & 136 & 8 & 171 & 179 & 164 & 10 \\
\hline $14: 30$ & $125^{\mathrm{b}}$ & $176^{\mathrm{a}}$ & $158^{b}$ & 9 & 157 & 153 & 152 & 9 \\
\hline $16: 30$ & $163^{a, b}$ & $181^{\mathrm{a}}$ & $148^{\mathrm{b}}$ & 7 & 167 & 157 & 169 & 11 \\
\hline Daily mean & $143^{b}$ & $171^{\mathrm{a}}$ & $141^{\mathrm{b}}$ & 6 & 175 & 168 & 166 & 5 \\
\hline
\end{tabular}

a,b Means that have a common letter in the same row of the experiment did not differ.

* Treatment $\times$ sampling time interaction, $\mathrm{P}<0.08$.

higher ratio of urinary $\mathrm{PD}$ : creatinine in Exp. 1, similar to urinary PD. However, the ratio was comparable between (D) and (E) groups and the ratio of (D) was unexpectedly higher than that of $(\mathrm{F})$ in Exp. 2, as well as all the ratios in Exp. 1. It might not be able to rely urinary PD : creatinine ratio as the estimator of microbial protein production, because protein-energy nutrition has been reported to affect not only endogenous allantoin excretion $^{6)}$ but also urinary creatinine ${ }^{11}$.

The fluctuations of plasma allantoin concentrations with the lapse of time were relatively higher in both experiments (within ca. $20 \%$ of daily mean), although CHEN et al. ${ }^{7)}$ observed small changes within a day even in steers under the condition of once daily feeding. The reason of the inconsistent results was not clear. The daily mean of plasma allantoin concentrations and the concentrations at 08 : $30,14: 30$ and $16: 30$ were significantly higher in calves supplemented urea in Exp. 1, and the time-course of the concentrations also tended to be different among the treatment groups (treatment $\times$ sampling time interaction, $P<$ 0.08). Also, calves fed the basal diets at $2.1 \mathrm{~g}$ $\mathrm{CP} / \mathrm{kg} \mathrm{BW}$ (i.e., (A) and (C) groups) tended to show the lower concentrations than those fed the basal ration of 2.8 and $3.7 \mathrm{~g} \mathrm{CP} / \mathrm{kg} \mathrm{BW}$, although it could not be evaluated statistically. In Exp. 2, however, urea supplement to the basal diet hardly affected plasma allantoin concentrations, in spite of the increase in urinary PD. CHEN et al. ${ }^{5)}$ suggested that urinary excretion of allantoin could not be deduced from plasma allantoin concentration at any one particular time of the day because of the diurnal variation in the flow of microbial matters from 
the rumen and into the small intestine.

Not only urinary PD : creatinine ratio but also plasma allantoin concentration was suggested to be not so sensible as urinary excretion of $\mathrm{PD}$ as an estimator of intestinal flow of microbial protein. Plasma allantoin as the estimator might be applicable only in case of quite large differences of microbial protein production among calves having a similar weight, because a linear decline of the plasma allantoin concentration related to age was shown in our study (FunABA et al., submitted). To clarify the factors affecting allantoin metabolism, plasma allantoin concentration and urinary PD : creatinine ratio will be needed to be examined in calves different in microbial protein production but similar protein 1-1 energy status.

\section{Acknowledgments}

We wish to thank Dr. Mitsuto Matsumoto, Tohoku National Agricultural Experiment Station, for suggestions on analysis of plasma allantoin, and Mr. Kohsaku TAKEDA for his helpful technical assistance.

\section{References}

1) $\mathrm{ABE}, M$. and $T$. IRIKI, Urinary excretion of purine derivatives in early-weaned calves. Anim. Sci. Techonol. (Jpn.), 62 : 1062-1064. 1991.

2) Abe, M., M. Funaba, T. Iriki and A. Ogawa, Evaluation of ruminally degradable dietary protein as a nitrogen source for rumen microbes. Anim. Sci. Technol. (Jpn.), $63: 1240-$ 1246. 1992.

3) AbE, M., M. Funaba, T. Kawashima and T. Iriki, Urinary excretion of purine derivatives and intestinal flow of microbial protein in calves before and after weaning at 11 weeks of age. Anim. Sci. Technol. (Jpn.), 64 : 1005-1009. 1993.

4) Chen, X.B., E.R. ØRSKov and F.D. DEB. HovelL, Excretion of purine derivatives by ruminants: endogenous excretion, differences between cattle and sheep. Br. J. Nutr. 63 : 121-129. 1990.

5) Chen, X.B., D.J. KYLE, E.R. ØRSKOV and F.D.
Deb. Hovell, Renal clearance of plasma allantoin in sheep. Exp. Physiol., $76: 59-65$. 1991.

6) Chen, X.B. S.A. Chowdhury, F.D. Deb. Hovell, E.R. ØRSKov and D.J. KYLE, Endogenous allantoin excretion in response to changes in protein supply in sheep. J. Nutr., 122 : 22262232. 1992.

7) Chen, X.B., G. Grubic, E.R. Ørskov and P. OsuJ, Effect of feeding frequency on diurnal variation in plasma and urinary purine derivatives in steers. Anim. Prod., 55 : 185-191. 1992.

8) Fujhhara, T., E.R. Ørskov and P.J. ReEds, The effect of protein infusion on urinary excretion of purine derivatives in ruminants nourished by intragastric nutrition. J. Agric. Sci. (Camb.), $109: 7-12.1987$.

9) Matsumoto, M., T. Kobayashi and H. Itabashl, Effects of $\mathrm{CP}$ content and rumen $\mathrm{CP}$ degradability of diet on the urinary allantoin excretion in goats. Jpn. Zootech, Sci., 61 : 505511. 1990.

10) Matsuoka, S., Y. Matsuoka and H. Fujita, Effects of the level of protein and energy intake and dietary nitrogen source on the distribution of nitrogenous compounds in the urine of sheep. Jpn. J. Zootech. Sci., $59: 261^{-}$ 268. 1988.

11) Matsuoka, S., S. Kogawa and H. Fujita, Changes in urinary excretion of nitrogenous compounds with progressing starvation in sheep. Jpn. J. Zootech. Sci., 59 : 752-754. 1988.

12) NRC, Nutrient Requirements of Dairy Cattle. 6th revised ed. National Academic Press, Washington, D.C. 1988.

13) Puchala, R. and G.W. Kulasek, Estimation of microbial protein flow from the rumen of sheep using microbial nucleic acid and urinary excretion of purine derivatives. Can. J. Anim. Sci. $72: 821-830.1992$.

14) SAS. User's Guide. Statistics. Statistical Analysis System Institute, Inc. Cary, N.C. 1985.

15) Topps, J.H. and R.C. Elliott, Relationships between concentrations of ruminal nucleic acid and excretion of purine derivatives by sheep. Nature 205 : 498-499. 1965.

16) Young, E.G. and C.F. ConWAy, On the estimaLion of allantoin by the Rimini-Schryver reaction. J. Biol. Chem. 142 : 839-852. 1942. 